Miodrag V. Zdujić, Slobodan D. Petrović ${ }^{2}$, Nataša V. Valentićé, Dušan Ž. Mijin ${ }^{2 *}$

${ }^{1}$ Institute of Technical Sciences of the Serbian Academy of Sciences and Arts, Belgrade, Serbia, ${ }^{2}$ University of Belgrade, Faculty of Technology and Metallurgy, Belgrade, Serbia
Scientific paper

ISSN 0351-9465, E-ISSN 2466-2585

UDC:661.77:662.2.035:66.091.3+

doi: $10.5937 /$ zasmat $1903229 Z$

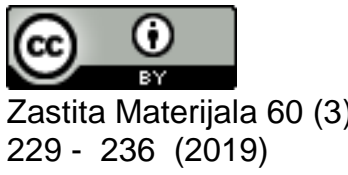

\title{
On the synthesis of 3-cyano-6-hydroxy-4-methyl-2-pyridone at room temperature
}

\begin{abstract}
Milling of cyanoacetamide and acetoacetic ester as reactants, in the presence of $\mathrm{KOH}$ as the catalyst and ethanol as a viscous control agent (VCA) was performed in a planetary ball mill with the goal of investigating the effect of mechanochemical treatment for the synthesis of 3-cyano-6hydroxy-4-methyl-2-pyridone at room temperature. The mechanochemical synthesis was performed under various milling parameters, i.e. milling time up to $4 \mathrm{~h}$, number and size of balls, angular velocity as well as molar ratio of reactants and the amount of catalyst. The obtained product was characterized by m.p., UV, IR and NMR data. It was fond that the dominant process parameter is the milling time while others are of less importance. The highest isolated yield after milling was up to $56 \%$. The combination of milling and aging increase yield over $60 \%$.
\end{abstract}

Keywords: cyanoacetamide, acetoacetic ester, mechanochemical synthesis, planetary ball mill, optimization.

\section{INTRODUCTION}

Mechanochemical treatment by ball milling is a well-known method for the modification, activation and synthesis of various classes of materials [1]. This versatile technique, basically applied to the particle size reduction and homogenization of ceramic mixtures, currently has been applied for the synthesis of catalysts, nanoparticles, dyes, pigments and so on [2]. It has been also extended to organic synthesis application [3], and recently for the preparation of nanosuspensions with the primary aim of overcoming the poor solubility of drugs (pharmaceutical nanocrystals) [4].

During the course of mechanochemical treatment, various solid-solid, solid-liquid and solidgas chemical reactions may take place. A mechanochemical reaction is a chemical reaction in which mechanical energy induces the reaction [5]. Numerous examples of mechanochemical reactions have been given in the literature [6]. However, it should be noted that the phenomena that take place during the mechanochemical treatment are extremely complex and insufficiently known.

\footnotetext{
${ }^{*}$ Corresponding author: Dušan Ž. Mijin

E-mail: kavur@tmf.bg.ac.rs

Paper received: 12. 03. 2019.

Paper corrected: 13. 05. 2019.

Paper accepted: 16. 05. 2019.

Paper is available on the website: www.idk.org.rs/journal
}

Nowadays, mechanochemistry, namely mechanochemical treatment has been realized as an eco-friendly and cost-efficient tool for various organic reactions, such as oxidations, reductions, condensations, transition metal-catalyzed coupling reactions, nucleophilic additions, cascade reactions, many of which were performed under solvent-free conditions [7,8]. Different organic compounds, including heterocycles, important in the synthetic and pharmaceutical chemistry due to their biological activity, were obtained using mechanochemistry.

Pyridones (2- and 4-pyridones) are pyridine derivatives. Actually, 2- and 4-pyridones are tautomers of 2- and 4-hydroxy pyridines, respectively. The 2-pyridone structure can be found in many synthetic compounds as well as in natural ones; some of them have biological activity, and some are useful as colorants. Milrinone [9] is a 2pyridone derivative which is a cardiotonic agent used in the therapy of heart failure. Similar compounds with the 2-pyridone structure and biological activity are amrinone [10] and loprinone [9]. In addition, some 2-pyridone derivatives possess antibiotic activity. It was reported that two new 2-pyridones (trichodin $A$ and $B$ ) isolated from marine fungus can inhibit Staphylococcus epidermidis [11]. Other 2-pyridones were synthesized which are active against Bacillus [anthracis] [12]. Pilicides are ring-fused 2-pyridone 
derivatives which also exhibit antibacterial activity [13].

2-Pyridones are the starting compounds for the synthesis of other biological active compounds, like nevirapine (i.e., 11-cyclopropyl-5,11-dihydro-4methyl-6H-dipyrido[2,3-b:3',2'-e] [1,4]diazepin-6one) which is an anti-HIV agent and can be obtained from 3-cyano-6-hydroxy-4-methyl-2pyridone [14]. 5-Pyridylcyclohexane-1,3-dione derivatives are produced from 2-pyridones and possess herbicidal activity [15]. Some 6-hydroxy-2pyridones and their derivatives can be used for the preparation of pharmaceutical compositions which inhibit the uridine phosphorylase enzyme and increase the effectiveness of antineoplastics, when they are used in combination [16]. It was found that 3-cyano-6-hydroxy-4-methyl-2-pyridone is efficient in the protection of intestinal mucosa as well in the inhibition of hUP1 enzyme [17]. In addition, some 2-pyridones exhibit anticonvulsant activity [18].

The application of 2-pyridones in the synthesis of arylazo pyridone dyes is much more abundant. Substituted 2-pyridones are used in the synthesis of commercial dyes like Disperse Yellow 119, Disperse Yellow 211 and Disperse Yellow 114 [19]. Many research papers, patents and patent applications deal with the synthesis and application of arylazo pyridone dyes [19-22]; including 3- cyano-6-hydroxy-4-methyl-2-pyridone as the starting molecule for arylazo pyridone dyes preparation.

2-Pyridones can be obtained in different ways [23]. Usually, a ring closing reaction is used. Combinations of various starting materials were used. Among others, activated methylene compounds are combined with carbonyl compounds [24-30]. In these reactions, ring closure can be achieved by classical heating (water bath, oil bath etc.) [24, 30], or microwave heating [28]. Various catalysts can be used, inorganic as well as organic, including enzymes and amino acids [31, 32].

In this paper, the mechanochemical synthesis of 3-cyano-6-hydroxy-4-methyl-2-pyridone (3), as model compound, was investigated in order to establish optimal reaction conditions for 2-pyridone synthesis (Scheme 1). A number of parameters were varied such as mass of reactants, molar ratio of reactants, reaction time, amount of the catalyst and the solvent, number and size of balls. The obtained product was characterized by its melting point, FT-IR, UV and NMR data. It should be pointed out, that to the best of our knowledge, this is the first attempt to synthesize 3-cyano-6hydroxy-4-methyl-2-pyridone (3) by means of mechanochemical treatment.<smiles>CCOC(=O)CC(C)=O</smiles><smiles>N#CCC(N)=O</smiles><smiles>Cc1cc(O)[nH]c(=O)c1C#N</smiles>

Scheme 1. Synthesis of 3-cyano-6-hydroxy-4-methyl-2-pyridone (3)

Šema 1. Sinteza 3-cijano-6-hidroksi-4-metil-2-piridona (3)

\section{EXPERIMENTAL PART}

\subsection{Materials and methods}

Cyanoacetamide (2) (99\%) was obtained from Across Organic (USA), while acetoacetic ester (1) (ethyl acetoacetate, pract.) was obtained from Fluka (Germany). Potassium hydroxide was purchased from Across Organic (extra pure) and ethanol (>98.5\%) from Merck. Hydrochloric acid (ACS reagent, 37\%) was obtained from Sigma (Germany).

The melting points were determined using Stuart SMP30 (UK), an automated melting point system, in capillary tubes. IR data were obtained on a Nicolet iS10 spectrometer (Thermo Scientific,
USA) ATR (Attenuated total reflection). A Bruker, USA, Ascend $400(400 \mathrm{MHz})$ was used to acquire ${ }^{1} \mathrm{H}$ NMR data (room temperature, DMSO- $\mathrm{d}_{6}$ ). The UV absorption spectra were recorded on a Shimadzu UV-Vis 1700 (Japan) spectrophotometer at a concentration $5 \cdot 10^{-5} \mathrm{~mol} \cdot \mathrm{L}^{-1}$.

\subsection{Mechanochemical synthesis}

Mechanochemical synthesis of the 3-cyano-6hydroxy-4-methyl-2-pyridone (3) was carried out in air atmosphere using a planetary ball mill PQ-N04 (Across International, USA) with two stainless steel vials of $100 \mathrm{~cm}^{3}$ volume and stainless steel balls. Most of the experiments were done with a mixture

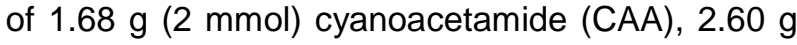


(2 mmol) acetoacetic ester (ASE) as reagents, 1.12 $\mathrm{g} \mathrm{KOH}(2 \mathrm{mmol})$ as the catalyst and $11 \mathrm{~g}$ ethanol. The mass of the ethanol was carefully chosen by gradually adding ethanol during milling to obtain satisfying viscosity of the mixture which would allow free movement of the balls. Otherwise, without ethanol, reaction mixture tends to aggregate into nuggets or to stick to the vial walls and balls. Thus, ethanol may be considered as a viscous controlling agent (VCA). Molar ratios of reactants were also varied (CAA:ASE $=1: 1,1.25: 1$, $1.5: 1$, and vice versa). In order to investigate the effect of milling parameters on the reaction, the number of balls (either 5 or $10 \mathrm{~mm}$ diameter), total number of balls, angular velocity of vials (vial to sun disc angular velocity ratio was $2: 1$ ) and milling time were varied. Typically, parallel milling with two vials filled with 5 or $10 \mathrm{~mm}$ diameter balls but keeping the same balls-to-sample mass ratio was carried out at room temperature. It should be noted that for all experimental conditions the heating i.e. temperature rise of the vials during milling was not observed. Immediately after milling, hot water was poured into the vial to completely dissolve the reaction product, and the solution was then transferred to a beaker. The obtained solution was then acidified by the addition of concentrated $\mathrm{HCl}$. The formed white solid was isolated by filtration, washed with water and air dried. Characterization: m.p. 316.1-318.2 ${ }^{\circ} \mathrm{C}$ (lit. 315-320 ${ }^{\circ} \mathrm{C}$ [29]). ATR IR $\left(v / \mathrm{cm}^{-1}\right)$ : 2226, $1602 ;{ }^{1} \mathrm{H}$ NMR $(400 \mathrm{MHz}$, DMSO$\left.\mathrm{d}_{6}, \delta / \mathrm{ppm}\right): 2.23\left(3 \mathrm{H}, \mathrm{s}, \mathrm{CH}_{3}\right), 5.61(1 \mathrm{H}, \mathrm{s}, \mathrm{C} 5) ; \mathrm{UV}$ $\left(\mathrm{EtOH}, \lambda_{\max } / \mathrm{nm}\right): 324$.

\section{RESULTS AND DISCUSSION}

At first, the influence of cyanoacetamide and the initial amount of potassium hydroxide was investigated: the amount of the cyanoacetamide or potassium hydroxide was varied between 20 and $30 \mathrm{mmol}$. The ratio of reactants was in the range $1: 1$ to $1.5: 1$. Fig. 1 shows the influence of the initial amount of cyanoacetamide on the reaction yield. As can be seen, the product yield increases from the ratio $1: 1$ to $1.25: 1$ and then decreases. The obtained results were in accordance with the results obtained for the synthesis of arylazo pyridone dyes. In that synthesis, performed under microwave irradiation, the product was obtained by cyclization of cyanoacetamide with phenylazo acetylacetone, an increase of cyanoacetamide initial amount led to the higher yield [33]. The decrease of the reaction yield with the higher amount of cyanoacetamide might be due to the change in the viscosity of the reaction mixture which hinders the movement of balls, thus affecting the mixing of the reactants. Furthermore, the dependence depicted in Fig. 2 was obtained when the ratio between potassium hydroxide and cyanoacetamide was varied. As can be expected, in the absence of base as a catalyst no product was formed. The highest yield was obtained at the $1: 1$ ratio. The higher ratio again led to a decrease of the yield probably also due to the change of the viscoelastic contact between the milling balls and the reactants [34].

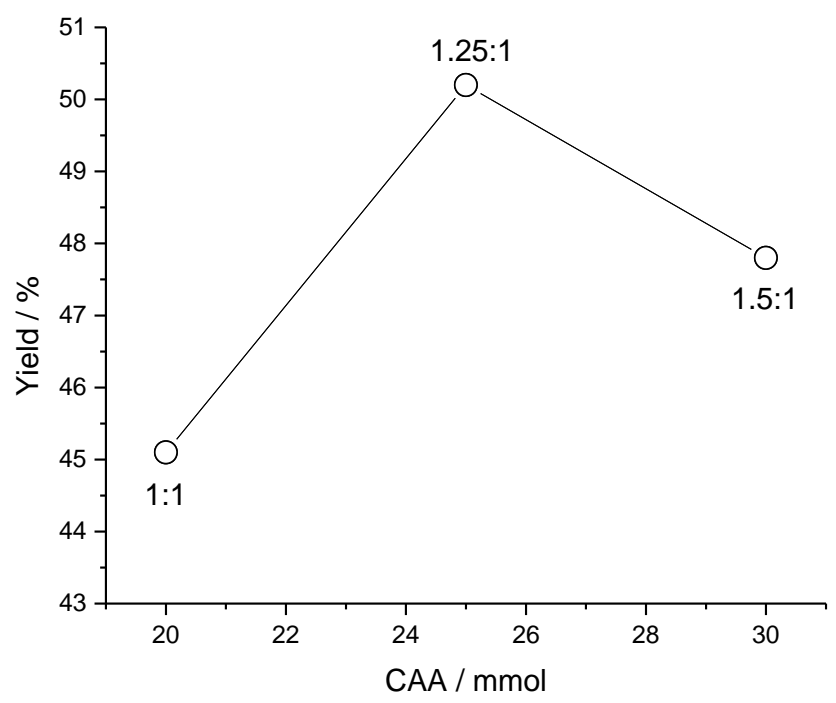

Figure 1. The influence of the initial amount of CAA on the isolated pyridone (3) yield (reaction time: $2 \mathrm{~h}$, number of balls: 17, ball diameter: $10 \mathrm{~mm}$, mass of balls: $62.5 \mathrm{~g}$, vial angular velocity: $600 \mathrm{rpm}$, mass of ethanol: $11 \mathrm{~g}$, ASE amount: $20 \mathrm{mmol}, \mathrm{KOH}$ amount: $20 \mathrm{mmol}$ )

Slika 1. Uticaj početne količine cijanoacetamida na prinos piridona (3) (reakciono vreme: 2 h, broj kuglica: 17, prečnik kuglice: $10 \mathrm{~mm}$, masa kuglica: $62,5 \mathrm{~g}$, ugaona brzina posude: $600 \mathrm{~min}^{-1}$, masa etanola: $11 \mathrm{~g}$, masa acetsirćetnog estra: $20 \mathrm{mmol}$, masa kalijum-hidroksida: $20 \mathrm{mmol}$ ) 


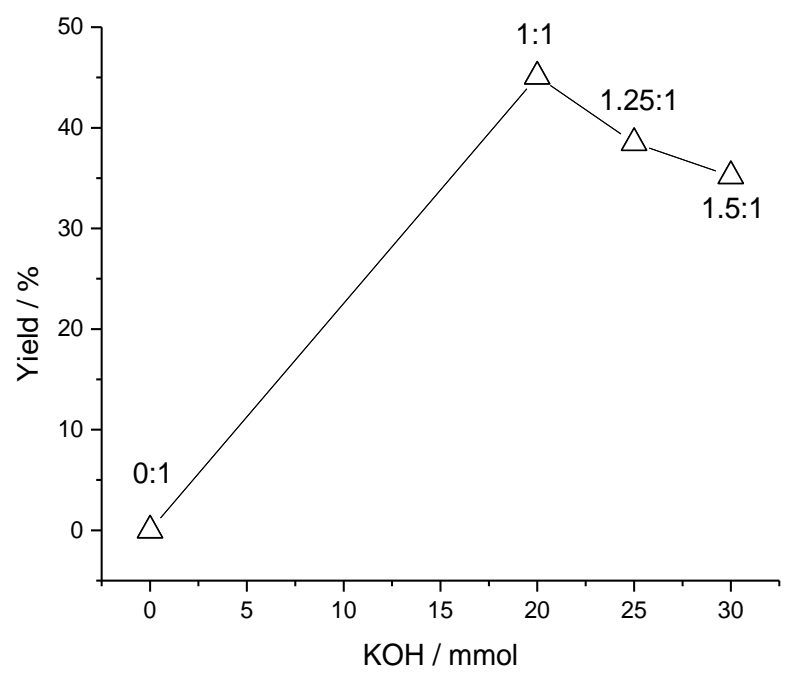

Figure 2. The influence of the initial amount of $\mathrm{KOH}$ on the isolated pyridone (3) yield (reaction time: $2 \mathrm{~h}$, number of balls: 17, ball diameter: $10 \mathrm{~mm}$, mass of balls: $62.5 \mathrm{~g}$, vial angular velocity: $600 \mathrm{rpm}$, mass of ethanol: $11 \mathrm{~g}$, CAA amount: $20 \mathrm{mmol}$, ASE amount: $20 \mathrm{mmol})$

Slika 2. Uticaj početne količine kalijum-hidroksida na prinos piridona (3) (reakciono vreme: 2 h, broj kuglica: 17, prečnik kuglice: $10 \mathrm{~mm}$, masa kuglica: $62,5 \mathrm{~g}$, ugaona brzina posude: $600 \mathrm{~min}^{-1}$, masa etanola: $11 \mathrm{~g}$, masa cijanoacetamida: $20 \mathrm{mmol}$, masa acetsirćetnog estra: $20 \mathrm{mmol}$ )

It should be noted that the reactions without the addition of ethanol as the viscous controlling agent and the alternative use of acetoacetic ester gave the product in a low yield (24\%). As a rule, the addition of a solvent/liquid modifies the mechanochemical reaction environment, and in such a case, milling may be considered as liquidassisted grinding [35]. The amount of $11 \mathrm{~g}$ (0.24 $\mathrm{mol}, 14 \mathrm{~mL}$ ) of ethanol was found to be the optimal. The ratio between the volume of the added solvent and the mass of reactants was found to be 2.59 $\mathrm{mL} / \mathrm{g}$. The use of acetoacetic ester in excess instead of ethanol gave the product in low yield due to the change in viscosity of the reaction mixture.

The influence of the reaction/milling time was also investigated, using the equimolar amount of the reactants (Fig. 3). The milling time was varied from $15 \mathrm{~min}$ up to $4 \mathrm{~h}$, while the product yield increased from $2.5 \%$ (15 $\mathrm{min}$ ) up to $56 \%$ after $4 \mathrm{~h}$. Prolonging the reaction time from 2 to $4 \mathrm{~h}$ increases the product yield by about $10 \%$. From the economical point of view, milling time of $2 \mathrm{~h}$ should be optimal. This reaction time is shorter in comparison to conventional synthesis ( $8 \mathrm{~h}$ ) [36] but longer than microwave synthesis (4 min) [37]. All three methods give similar product yields. When the reaction mixture was left at room temperature without milling for $24 \mathrm{~h}$ the reaction proceeded spontaneously. Thus, the reaction yield increased from $46 \%$ after $2 \mathrm{~h}$ of milling to $69 \%$ after $24 \mathrm{~h}$ of subsequent aging (50\% relative increase). On the other hand, when the reaction mixture $(20 \mathrm{mmol}$ of
ASE, $20 \mathrm{mmol}$ of CAA, $20 \mathrm{mmol}$ of $\mathrm{KOH}$ and $11 \mathrm{~g}$ of ethanol) was placed in a vial, manually mixed and left to stay at room temperature, after six days, the yield of $39 \%$ was obtained. This indicates that the reaction between cyanoacetamide and acetoacetic ester in the presence of $\mathrm{KOH}$ as the catalyst and ethanol as the viscous controlling agent proceeds slowly at room temperature.

In order to examine the effect of milling intensity, defined as a product of kinetic energy and the frequency of balls $[38,39]$ on the mechanochemical reaction, parallel milling with a different number of either 5 or $10 \mathrm{~mm}$ diameter balls, but keeping the same mass of the total number of balls was performed for $2 \mathrm{~h}$ of milling time. As can be seen in Fig. 4, the increase in the total mass of the balls has small effect on the pyridone (3) yield, except for the highest mass of balls $(241 \mathrm{~g})$, for which yield of 56 and $52 \%$, for 5 and $10 \mathrm{~mm}$ diameter balls was obtained respectively. Moreover, almost the same yield was obtained regardless of considerable different number of balls, e.g. 274 versus 66 of $5 \mathrm{~mm}$ and $10 \mathrm{~mm}$ diameter balls, respectively, suggesting that the milling intensity is a relevant parameter responsible for the reaction yield. It should be pointed out that even milling without balls leads to the reaction yielding about $39 \%$ of pyridone (3) (Fig. 4). Synthesis with smaller amounts of reactants ( $5 \mathrm{mmol}$ ) with $62.5 \mathrm{~g}$ of balls (17 balls, 10 $\mathrm{mm}$ ) also gave a lower yield (28\%) after $2 \mathrm{~h}$ of milling. 


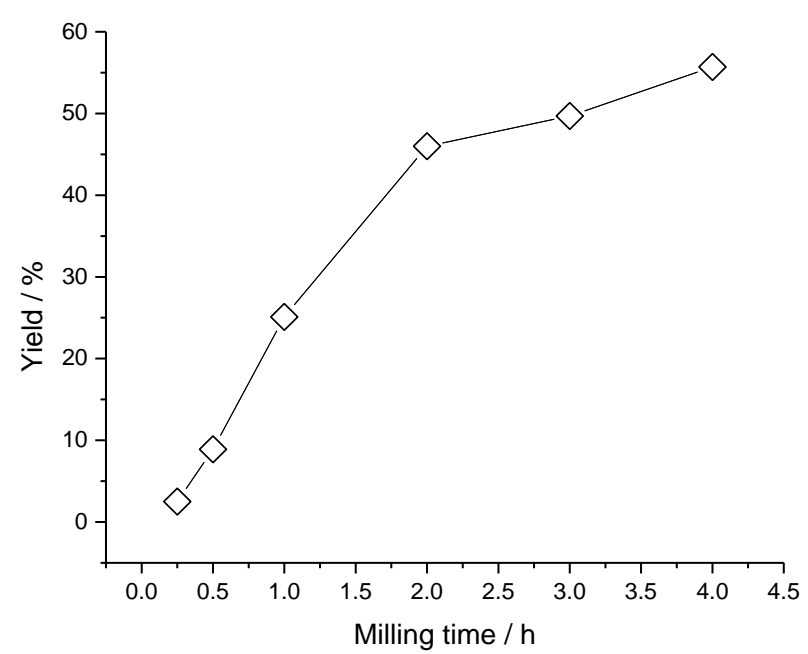

Figure 3. The influence of the reaction time on the isolated pyridone (3) yield (number of balls: 17, ball diameter: $10 \mathrm{~mm}$, mass of balls: $62.5 \mathrm{~g}$, vial angular velocity: $600 \mathrm{rpm}$, mass of ethanol: $11 \mathrm{~g}, C A A$ amount: $20 \mathrm{mmol}$, ASE amount: $20 \mathrm{mmol}, \mathrm{KOH}$ amount: $20 \mathrm{mmol}$ )

Slika 3. Uticaj reakcionog vremena na prinos piridona (3) (broj kuglica: 17, prečnik kuglice: $10 \mathrm{~mm}$, masa kuglica: 62,5 g, ugaona brzina posude: $600 \mathrm{~min}^{-1}$, masa etanola: $11 \mathrm{~g}$, masa cijanoacetamida: $20 \mathrm{mmol}$, masa acetsirćetnog estra: 20 mmol, masa kalijum-hidroksida: 20 mmol)

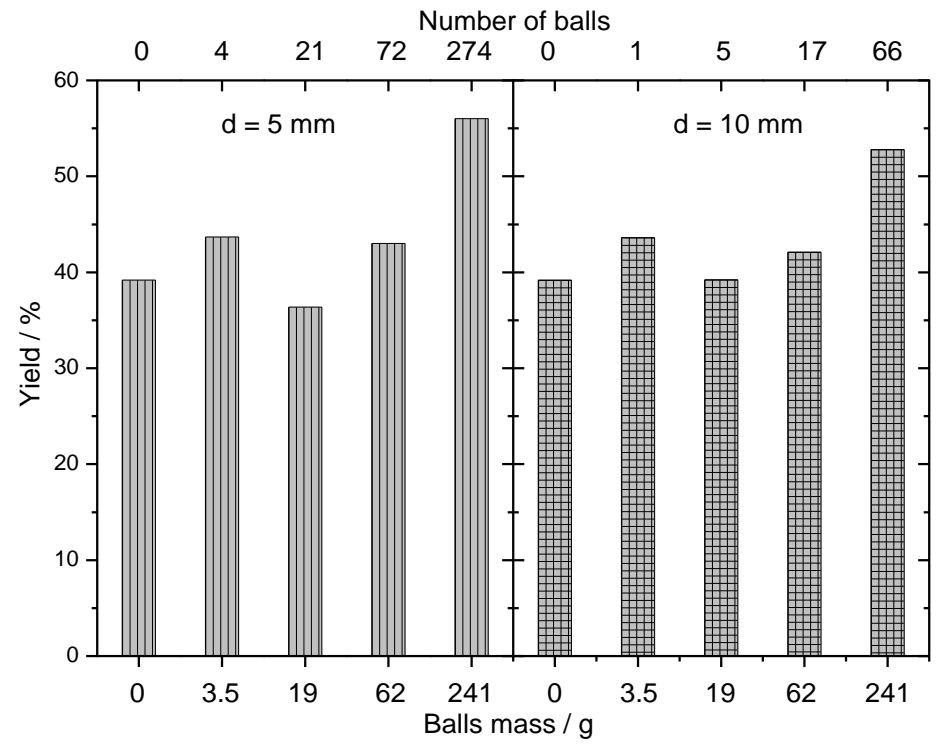

Figure 4. The influence of number and mass of $5 \mathrm{~mm}$ and $10 \mathrm{~mm}$ diameter balls on the isolated pyridone (3) yield (reaction time: $2 \mathrm{~h}$, vial angular velocity: $600 \mathrm{rpm}$, mass of ethanol: $11 \mathrm{~g}, C A A$ amount: $20 \mathrm{mmol}$, ASE amount: $20 \mathrm{mmol}, \mathrm{KOH}$ amount: $20 \mathrm{mmol}$ )

Slika 4. Uticaj broja i mase kuglica prečnika 5 i $10 \mathrm{~mm}$ na prinos piridona (3) (reakciono vreme: $2 \mathrm{~h}$, ugaona brzina posude: $600 \mathrm{~min}^{-1}$, masa etanola: $11 \mathrm{~g}$, masa cijanoacetamida: $20 \mathrm{mmol}$, masa acetsirćetnog estra: $20 \mathrm{mmol}$, masa kalijum-hidroksida: $20 \mathrm{mmol}$ )

Typically, the angular velocity of a planetary ball mill is one of the relevant milling parameters (among others such as a number and diameter of balls, ball filling degree, vial volume, balls-tosample mass ratio, vial/supporting disc angular velocity ratio) that governs kinetics and final product(s) of the mechanochemical synthesis of organic molecules [35]. In order to investigate its effect on the mechanochemical treatment of the given system, milling with 100, 300 and $600 \mathrm{rpm}$ angular velocity of two vials filled with 5 and $10 \mathrm{~mm}$ diameter balls was carried out. As can be seen from Fig. 5, remarkably lower yield was obtained with angular velocities of 100 and $300 \mathrm{rpm}$. Almost 
the same yields ( 43 and $42 \%$ for 5 and $10 \mathrm{~mm}$ ball diameter, respectively) for vial angular velocity of $600 \mathrm{rpm}$ again indicate that the milling intensity appears as a relevant milling parameter, while impact energy and frequency are less significant. For milling with $100 \mathrm{rpm}$ it was found that after opening the vials "slurry" was formed in both vials, whereby the balls were embedded into the pastelike mixture. Thus, the kinetic energy of the balls was insufficient to overcome viscous forces of the semi-liquid mixture. The higher pyridone (3) yield for angular velocity of $100 \mathrm{rpm}$ using $10 \mathrm{~mm}$ diameter balls in comparison to the $5 \mathrm{~mm}$ diameter balls is plausibly result of eight times higher kinetic energy of $10 \mathrm{~mm}$ diameter balls (assuming that the ball velocity is the same in both vials), which allowed prolonged balls movement until the viscous forces prevail.

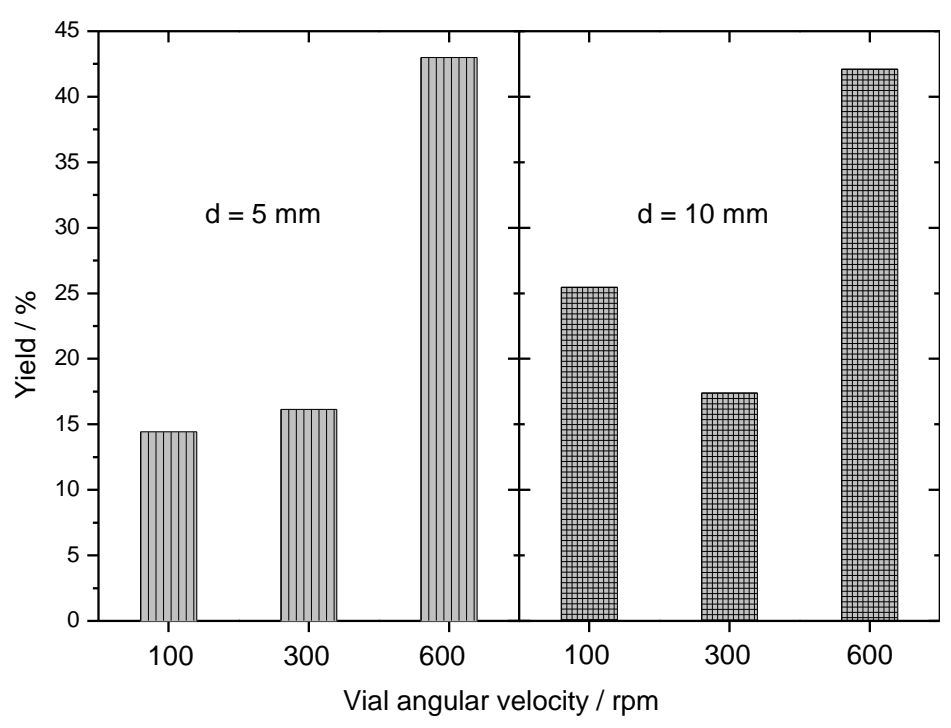

Figure 5. The influence of vial angular velocity on the isolated pyridone (3) yield (reaction time: $2 \mathrm{~h}$, number of balls: 17 and 73 for $10 \mathrm{~mm}$ and $5 \mathrm{~mm}$ diameter balls, mass of balls: $62.5 \mathrm{~g}$, mass of ethanol: 11 g, CAA amount: $20 \mathrm{mmol}$, ASE amount: $20 \mathrm{mmol}, \mathrm{KOH}$ amount: $20 \mathrm{mmol}$ )

Slika 5. Uticaj ugaone brzine posude na prinos piridona (3) (reakciono vreme: 2 h, broj kuglica: 17 i 73 prečnika 10 i $5 \mathrm{~mm}$, masa kuglica: 62,5 g, masa etanola: $11 \mathrm{~g}$, masa cijanoacetamida: $20 \mathrm{mmol}$, masa acetsirćetnog estra: $20 \mathrm{mmol}$, masa kalijum-hidroksida: $20 \mathrm{mmol}$ )

It should be noted that the synthesis was also performed in a beaker with a magnetic stirrer (with a yield of about $34 \%$ after $2 \mathrm{~h}$ at $900 \mathrm{rpm}$ was obtained), but in this case considerably larger amount of ethanol (about $30 \mathrm{~g}, 38 \mathrm{~mL}$ ) was needed to enable the proper work of the magnetic stirrer. Thus, it appears that precise control of the slurry viscosity, by adding ethanol as a viscosity control agent, is of crucial importance in order to accelerate such a reaction at room temperature.

\section{CONCLUSIONS}

The investigation of the initial amount of cyanoacetamide and potassium hydroxide on the reaction yield of 3-cyano-6-hydroxy-4-methyl-2pyridone (3) during mechanochemical synthesis at room temperature showed that the ratio between reactants should not be higher than 1.25:1 (cyanoacetamide : potassium hydroxide). The higher ratio led to a decrease of the yield probably due to the change of the viscoelastic contact between the milling balls and the reactants. It should be noted that a small amount of ethanol was added during synthesis, since the reactions without ethanol as viscous controlling agent gave the product in low yield.

The influence of the reaction/milling time showed that the optimal milling time should be $2 \mathrm{~h}$. By prolonging the reaction time from 2 to $4 \mathrm{~h}$ the product yield increased to $56 \%$. When the reaction mixture was left at room temperature after $2 \mathrm{~h}$ of milling, without milling for $24 \mathrm{~h}$, the reaction proceeded spontaneously, and $69 \%$ yield was achieved. The reaction between cyanoacetamide and acetoacetic ester in the presence of $\mathrm{KOH}$ and ethanol slowly proceeds at room temperature, since the yield of $39 \%$ was obtained when the reaction mixture was placed in a vial, manually mixed and leaved to stay at room temperature for six days.

The increase in the total mass of the balls has a minor effect on the pyridone (3) yield, except for the highest mass of balls $(241 \mathrm{~g}, 56 \%$ yield). Almost the same pyridone (3) yield was obtained 
regardless of considerable different number of balls, e.g. 274 versus 66 of $5 \mathrm{~mm}$ and $10 \mathrm{~mm}$ diameter balls, respectively, suggesting that the milling intensity is relevant parameter responsible for the reaction yield.

From the results obtained, it may be concluded that milling due to the mixing of viscous mixture promotes a room-temperature reaction. The dominant process parameter is milling time followed by milling intensity, while impact energy and frequency are less significant.

\section{Acknowledgment}

The authors gratefully acknowledge the financial support from the Ministry of Education, Science and Technological Development of the Republic of Serbia [grant numbers: 172013 and 45001].

\section{REFERENCES}

[1] L.Takacs (2013) The historical development of mechanochemistry, Chem. Soc. Rev., 42(18), 76497659.

[2] W.Jones, M.D.Eddleston (2014) Introductory Lecture: Mechanochemistry, a versatile synthesis strategy for new materials, Faraday Discuss., 170, 9-34.

[3] G.W.Wang (2013) Mechanochemical organic synthesis, Chem. Soc. Rev., 42(18), 7668-7700.

[4] M.Malamateri, K.M.G.Taylor, S.Malamataris, D. Douroumis, K.Kachrimanis (2018) Pharmaceutical nanocrystals: production by wet milling and applications, Drug Discov. Today, 23(3), 534-547.

[5] A.D.McNaught, A.Wilkinson, Eds. (1997) IUPAC Compendium of Chemical Technology (the "Gold Book"), 2nd ed., Blackwell Scientific Publications, Oxford.

[6] P.Baláž, M.Achimovičová, M.Baláž, P.Billik, Z. Cherkezova-Zheleva, J.M.Criado, F.Delogu, E. Dutková, E. Gaffet, F.J.Gotor, R.Kumar, I.Mitov, T. Rojac, M.Senna, A.Streletskii, K.Wieczorek-Ciurowa (2013) Hallmarks of mechanochemistry: from nanoparticles to technology, Chem. Soc. Rev., 42(18), 7571-7637.

[7] B.C.Ranu, A.Stolle, Eds. (2014) Ball Milling Towards Green Synthesis: Applications, Projects, Challenges, Royal Society of Chemistry, Cambridge.

[8] D.Margetić, V.Štrukil (2016) Mechanochemical Organic Synthesis, Elsevier, Amsterdam.

[9] J.M.Mirković, D.Ž.Mijin, S.D.Petrović (2013) Properties and synthesis of milrinone, Hem. Ind., 67(1), 17-25. (In Serbian)

[10] G.Pastelin, R.Mendez, E.Kabela, A.Farah (1983) The search for a digitalis substitute II milrinone (Win $47203)$ its action on the heart-lung preparation of the dog, Life Sci., 33(18), 1787-1796.

[11] B.Wu, V.Oesker, J.Wiese, R.Schmaljohann, J.F. Imhoff (2014) Two New Antibiotic Pyridones Produced by a Marine Fungus, Trichoderma sp. Strain MF106, Mar. Drugs, 12, 1208-1219.
[12] S.K.Tipparaju, S.Joyasawal, S.Forrester, D.C. Mulhearn, S.Pegan, M.E.Johnson, A.D.Mesecar, A.P. Kozikowski (2008) Design and Synthesis of 2Pyridones as Novel Inhibitors of the Bacillus Anthracis Enoyl-ACP Reductase, Bioorg. Med. Chem. Lett., 18(12), 3565-3569.

[13] R.Piatek, B.Zalewska-Piatek, K.Dzierzbicka, S. Makowiec, J.Pilipczuk, K.Szemiako, A.CyrankaCzaja, M.Wojciechowski (2013) Pilicides inhibit the FGL chaperone/usher assisted biogenesis of the $\mathrm{Dr}$ fimbrial polyadhesin from uropathogenic Escherichia coli, BMC Microbiology, 13(131), 1-12 .

[14] Q.Meng, W.Zeng, Q.Lai, Y.Li, W.Zhao (2006) Synthesis of nevirapine, Zhongguo Yiyao Gongye Zazhi, 37(1), 5-7. (CAN148:191910)

[15] G.J.Bird, R.J.Conway, G.J.Farquharson, K.G. Watson, P.G.Tucker (1984) Herbicidal 5pyridylcyclohexane-1,3-dione derivatives. EP patent appl., No. 104876.

[16] L.A.Basso, P.Machado, D.Renck, D.S.Santos (2015) Use of 6-hydroxy-2-pyridones and derivatives thereof for preparing a pharmaceutical composition that acts by inhibiting the human uridine phosphorylase enzyme. WO patent, No. 2015031968

[17] D.Renck, A.A.Santos, P.Machado, G.O.Petersen, T. G.Lopes, D.S.Santos, M.M.Campos, L.A.Basso (2014) Human uridine phosphorylase-1 inhibitors: a new approach to ameliorate 5-fluorouracil-induced intestinal mucositis, Invest. New Drugs, 32(6), 1301 1307.

[18] S.D.Deval, S.R.Pednekar, S.D.Samant, K.D. Deodhar, A.Y.Nimbkar (1982) Synthesis of some Mannich bases of substituted glutaconimides as anticonvulsant agents, Indian J. Chem., Sect B, 21B(11), 1056-1058.

[19] D.Ž.Mijin, G.S.Ušćumlić, N.V.Valentić, A.D. Marinković (2011) Synthesis of azo pyridone dyes, Hem. Ind., 65 (5), 517-532. (In Serbian)

[20] J.M.Park, C.Y.Jung, W.Yao, C.Jun, H.Song, J.Y. Jaung (2017) Synthesis of yellow pyridonylazo colorants and their application in dye-pigment hybrid colour filters for liquid crystal display, Color. Techn., 133(2), 158-164.

[21] S.Watanabe, Y.Moriki, K.-I.Nakayama, K.Inaba, M. Kato, M.Tanaka, T.Toyoda (2009) Yellow electrostatographic toner containing specific colorant. WO patent, No. 2009088034.

[22] D.Ž.Mijin, G.S.Ušćumlić, N.V.Valentić (2001) Synthesis and investigation of solvent effects on the ultraviolet absorption spectra of 5-substituted-4methyl-3-cyano-6-hydroxy-2-pyridones, J. Serb. Chem. Soc., 66(8), 507-516.

[23] P.A.Keller (2005) Product Class 2: Pyridinones and Related Systems, in Science of Synthesis, 15: Category 2, Hetarenes and Related Ring Systems, Vol. 15, D. StC. Black, Thieme, Stuttgrat, p. 285387.

[24] U.Basu (1931) $\beta$-Diketones in ring formation, J. Indian Chem. Soc., 8, 319-328.

[25] H.J.Quadbeck-Seeger (1977) 3-Cyano-2-pyridones. DE patent, No. 2531035. 
[26] V.S.Hawaldar, S.V.Sunthankar (1980) A novel method for the synthesis of pyridines, Indian $\mathrm{J}$. Chem., Sect B, 19B(2), 151-152.

[27] J.Gmaj, C.Sosnowski, Z.Zaremba, B.Mrowinski, (1990) Method for producing pyridone derivatives useful as dye intermediates. PL patent, No. 150312.

[28] H.Schmid (1994) Process for the preparation of pyridone compounds. DE patent, No. 4314430.

[29] D.Mijin, M.M.Mišić-Vuković (1994) Investigation of the reaction conditions for the synthesis of 4,6disubstituted 3-cyano-2-pyridones and 4-methyl-3cyano-6-hydroxy-2-pyridone, J. Serb. Chem. Soc., 59(12), 959-965.

[30] D.Ž.Mijin, G.S.Ušćumlic, N.V.Valentić (2001) Synthesis and investigation of solvent effects on the ultraviolet absorption spectra of 5-substituted-4methyl-3-cyano-6-hydroxy-2-pyridones, J. Serb. Chem. Soc., 66(8), 507-516.

[31] M.Mišić-Vuković, D.Mijin, M.Radojković-Veličković, N.Valentić, V.Krstić (1998) Condensation of 1,3diketones with cyanoacetamide:4,6-disubstituted-3cyano-2-pyridones, J. Serb. Chem. Soc., 63(8), 585-599.

[32] N.Ž.Prlainović, N.Ž.Šekuljica, J.M.Mirković, D. Ž. Mijin (2017) Synthesis of 4,6-dimethyl-3-cyano-2pyridone catalysed by amino acids, Zaštita Materijala, 58(1), 80-85. (In Serbian)

[33] D.Ž.Mijin, M.Baghbanzadeh, C.Reidlinger, C.Oliver Kappe (2010) The microwave-assisted synthesis of 5-arylazo-4,6-disubstituted-3-cyano-2-pyridone dyes, Dyes Pigm., 85(1-2), 73-78.

[34] J.L.Howard, Q.Cao, D.L.Browne (2018) Mechanochemistry as an emerging tool for molecular synthesis: what can it offer?, Chem. Sci., 9, 3080-3094.

[35] A.Stolle, R.Schmidt, K.Jacob (2014) Scale-up of organic reactions in ball mills: process intensification with regard to energy efficiency and economy of scale, Faraday Discuss., 170, 267-286

[36] J.M.Bobbitt, D.A.Scola (1960) Synthesis of isoquinoline alkaloids. II. The synthesis and reactions of 4-methyl-3-pyridinecarboxaldehyde and other 4-methyl-3-substituted pyridines, J. Org. Chem., 25(4), 560-564.

[37] J.M.Dostanić, D.R.Lončarević, P.T.Banković, O.G. Cvetković, D.M.Jovanović, D.Ž.Mijin (2011) Influence of process parameters on the photodegradation of synthesized azo pyridone dye in $\mathrm{TiO}_{2}$ water suspension under simulated sunlight, J. Environ. Sci. Health A Tox. Hazard. Subst. Environ. Eng., 46(1), 70-79.

[38] A.lasonna, M.Magini (1996) Power measurements during mechanical milling. An experimental way to investigate the energy transfer phenomena, Acta Mater., 44(3), 1109-1117.

[39] M.Magini, C.Colella, A.lasonna, F.Padella (1998) Power measurements during mechanical milling II. The case of "single path cumulative" solid state reaction, Acta Mater., 46(8), 2841-2850.

\section{IZVOD}

\section{O SINTEZI 3-CIJANO-6-HIDROKSI-4-METIL-2-PIRIDONA NA SOBNOJ TEMPERATURI}

Mlevenje cijanoacetoamida (2) i acetsirćetnog estra (1) kao reaktanata, u prisustvu KOH kao katalizatora i etanola kao agensa kojim se kontroliše viskoznost, izvedeno je u planetarnom mlinu radi ispitivanja mogućnosti mehanohemijske sinteze 3-cijano-6-hidroksi-4-metil-2-piridona (3) na sobnoj temperaturi. Mehanohemijski tretman je izveden sa različitim parametrima mlevenja: vremenom mlevenja do $4 \mathrm{~h}$, različitom veličinom i brojem kuglica, različitom brzinom obrtanja, kao i različitim molarnim odnosom reaktanata $i$ katalizatora. Dobijeni proizvod je okarakterisan određivanjem temperature topljenja, UV, IR i NMR analizama. Nađeno je da je dominantni procesni parametar vreme mlevenja, dok su ostali od manjeg uticaja. Najveći prinos izolovanog proizvoda je oko $56 \%$, dok se naknadnim „odležavanjem“ prinos povećava preko $60 \%$.

Ključne reči: cijanoacetamid, acetsirćetni estar, mehanohemijska sinteza, planetarni mlin sa kuglama, optimizacija.

Naučni rad

Rad primljen: 12. 03. 2019.

Rad korigovan: 13. 05. 2019.

Rad prihvaćen: 16. 05. 2019.

Rad je dostupan na sajtu: www.idk.org.rs/casopis

(C) 2019 Authors. Published by Engineering Society for Corrosion. This article is an open access article distributed under the terms and conditions of the Creative Commons Attribution 4.0 International license (https://creativecommons.org/licenses/by/4.0/) 